ルのチェーブ及びパルプを使用する。

L. ダンデーロール

外国では本体及網にモネルを使用する。我が国では 18〜8 ステンレスで作られて好結果が得られている。

M. プレス及白水系統

前記白水受の項汇述べたよ 5に 18〜8 系ステンレス で良結果が得られている。

N. ブロークビーター

前壾ビーターの項と同樣につき説明は省略する。

\section{8. 丸網抄紙機}

A. レギェレーチングボックス

18〜8ステンレスのシート, 型物, 证付板, 及び台 板等体用与ればよい。

B. ヘッドボックス

削記フローボックスの項に述べた通りにつき省略す る。

C. 抄 槽(バット)

洗滌, 清浄の容易, 迅速が仕事の上の最大要件であ ることは前記フローボックスの項に述べた通りである。 SUS-12 型ステンレス及びモネルのいろいろの形で使 用される。

D. 丸細モルド

ニッケル，モネル又は18〜8ステンレスをワイヤー 網等に使用する。

\section{9. 塗工及びサイジング}

A. サイズ用タンク

ルッケンニッケル合板が变色を防ぐのに用いられ る。

B. サイズブレス桶

モネルシートを梣用

C. 攀士タンク

モネル使用。

\section{0. その他一般}

A. 配管全般

以上, 列記諸機械への洨体輸送, 資料輸送等瓦斯導 管に注一般 18〜8 系ステンレスが大量に使用されてい る。特に配管系統は漏油のもたらす影響が非常に大き く, 工場の安全衛生, 清潔の面加らも看過ず゙からざ るものがある。

B. ポンプ, 送風機, バルブ, ニック類

A 項と密接な関連性があり，これが応用效果も前記 と同一につき省略する。この場合大部分が 18 系ス テンレス鋳物が使用されている。
C. ボールト，ナット類

ボールトナット類は一般に直接薬液に接触しないた めに軟鋼製品を以って代用されているが，知らず知ら ずの間に應蝕し漏洩の原因になる。ステンレスの場合， 㑛蝕防止は勿論であるが機器の分解掃除の場合, 発錆 の顧虑なきため, 取外し容易に乙短時間に目的の作業 を完了し得るを以ってこれが使用個所も逐年増加の傾 向がある。

\section{結び}

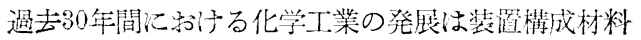
特にステンレスの出現によるところが非常に多い。特 に高温の亚硫酸ガス回収，間接蒸著等の装置において は砲金，鉛に代って谷種材料に大量に使用せられ酎久 的能率的に進少改善された。然るにその他の一般製紙 パルプ装置水おいては好適な凟材の選択と，外的条件 の制約から，末だ改善に至らざるものもあるのが非常 に多いと思考される。

現在パルプや㹈䋊工場では，その生産を最大限にす るため，必要の最低限の改造や増設は行らべきで，そ の場合本文が多少なりとも参考とならば幸甚と存じま 京。

\section{西独の紙パルプ工業の発展}

西独のパルプ用材に関する問題は，使用時における 木材の水分が18〜20\%以下である事奏で説明できる。 これは選択的伐採並びに運儥が重量単位の鉄道又はト ラックによる木材輸送に园る。木材の水分の低いこと は，化学的又は機栈的処理により得られるパルプ品質 に有菁のみならず，バーキングの間の木材ロスに関し ても不利益である。これがこの数年間に木材前処理法 が発達するまで, フリクションバーキングがドイッ工 場で利用し得なかった理由である。前処理は普通, 大 きな木製ヴァット内で, $2 \sim 3$ 時閒, $190^{\circ} \mathrm{F}$ で蒸す。 前処理した木村のバーキングにドラムバーカーの採用 により，村ロスは12〜16\%から 1\%以下になった。然 乙乾いた木材から生産されるパルプの貧弱な品䓄は, 北米で得られているマシーン速度及び效率に荎するた 
めに，な扮解決されるねね゙なら刚問題である。

これらの困難にも倸わらず，戦後のドイッ製綎工業 の発展梳しい。

\section{パルプの生産}

生座增進のためのドイツ紙分産業の努力は主として G P 及び製絓の分野でなされた。酉独炕クラフトパ

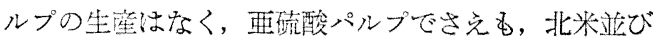
にスカンジナビヤの大工場のよ5に安く生産すること 蚮困難である。後者の経佩は，木材輸出の代りに增々 紙パルプを生産し売込むことである。故汇彼等は木材

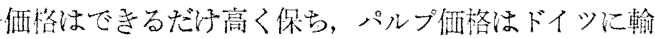
出するに必要なだけ低く維持している。実際，これが ドイッのパルプ工業の状態が一般に貧困で，大きなパ ルプ工場でさ光すいま票で配当金が払党なかった口つ の理由である。

\section{蒸気蒸し砕木パルプ}

クラフトパルプが輸入からだけ得られるという事実 が，四独の蒸父むし硴木パルプの比較的に重要な地位

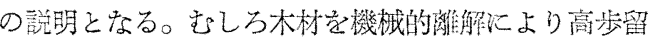
りで高、強度性質索得るこの方法は，CGP の初期段 階と思方れる。トラブルは木材を 4 万時間, $300^{\circ} \mathbf{F}$ で蒸気先しすること（中性西酼酸で蒸解する代り）飞 より，瞕褐色のフォイバーが得られることで，これが このパルプ材料责，擬革板紙，包湾絓等が数種の特種 な製品への利用に制限している。

故

紙

パルプ材価の高いため，故悢の利用は戦後着々と增 大し，現在框，板紙総生産高の 36.20\%である。利用さ 孔る故絠の大部分が，下級の薄紙，包装紙及び板紙の整 造に，ケミカルパルプを加えることないしばしば蒸気

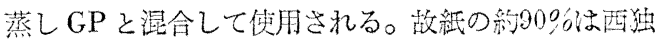
内部から得られている。西独沈括いて一人当 $1201 \mathrm{lbs} . の$ (米国の 1 人当紙消費量は $400 \mathrm{lbs}$.) 必要卜ン数 (1956 年，973,860トン) を供給することはなかなか困難で めるから，故紲でつくられる紙板紙のパーセンティジ 怯著しい。

\section{紙の種類}

西独では二三の土場がミミカルパルプの生産を併設 しているに過ぎ双が，殆んぞが $\mathrm{GP}$ を自家棐造してい る。最近数年の明確な傾向は，高級綎の製造汇向って いる。この理由は新聞紙この他の下級紙では利益が少 ないからである。これは，主として木材価格が比較的

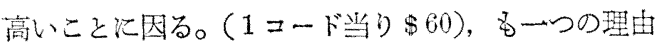
はスカンジナビヤ諾国による新聞絓領域の激しい競争,

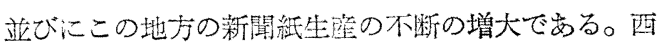
独にもスピード $2,000 \mathrm{ft} / \mathrm{min}$ の近代的な新聞絓マシー
ンがあるが，最近に据付けた設備の殆えぞはグラビヤ 用气の他高級紙用のものである。

これ関してドイッのグラビヤ坟品質が北米の气れ とは異ること学知らねばならない。後者では,グラビ ヤ紙は新聞紙にスーパーキャレンダーをか汸，地合と 表面をわずか汇改善した程度であるが，一方ドイッで はグラビア紙は，250\%悉でのクレーを含名，仕上げの 高級な紙である。この種の紙は，マシーンスピード $1,400 \mathrm{ft} / \mathrm{min}$ で低価格で慜造されるので，現在まで、 シーンコーテッド紙の採用を阻止している。大きな週 刊雑誌で，グラビヤ紙からマシーンコーテッド紙に変 更したものは，その慗造設徣が利用できても，いまの 所ない。ドイツ紙パルプ生産の内容は別表の通りであ る。

西独の悢板絽の生酸，1956年

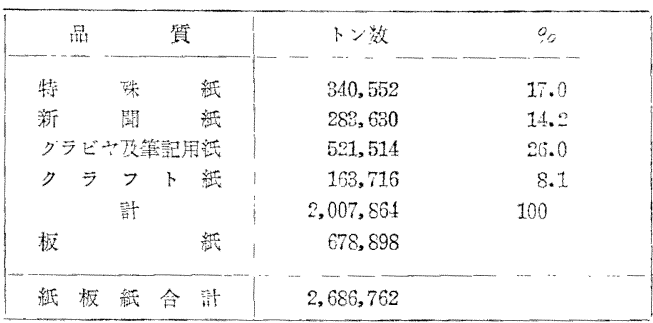

(ペーパートレードジャーナルより一特公票川)

\section{Chemipulp Process Ltd. の Jack Grant 氏のスウェーデン工場見学記}

北スウェーデンの紙パルプさ場を最近詰間し，彼地

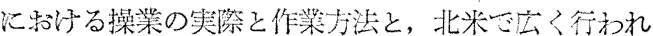
ている操業とを比較観察してみた。アメリカ市塨に輸 出されるスウェーデンのパルプが，魔少くから強いこ とは周知の既定の事実であって，他の条件さ光符しけ れば，消費者は機会があれれば，常にスウェーデンのパ ルプの購入党欲している。

私の考えでは，この旅行中の観察から，スウニーデ ンのパルプの優秀なる品質の主たる理由は次の点と思 われる。

1. 森林の手入れ

2. 皮さき及びクリーニングに際して木林の念入り 